\title{
CHALLENGES OF FEMALE ENTREPRENEURS IN TRANSITION COUNTRIES: CASE STUDY OF KOSOVO
}

\section{Prof. Ass. Rrezarta GASHI, MSc. Hana GASHI}

AAB College, Faculty of Economics, rrezartag@gmail.com

University of Prishtina, Faculty of Economics, gashihana5@gmail.com

\begin{tabular}{ll}
\hline $\begin{array}{l}\text { Article history: } \\
\text { Accepted 17 April } 2019\end{array}$ & A b S t $\mathbf{~ a ~ c ~ t ~}$ \\
Available online 30 April 2019 & Opportunely in the time of globalization, female entrepreneurs, including those doing business in \\
& countries in transition, are moving towards the booming of their businesses. Apart from the \\
Keywords: & advantages they have in the period their countries are transitioning, female entrepreneurs also are \\
Challenges, & faced with many challenges. These challenges are faced by female entrepreneurs who are doing \\
Women, & business in Kosovo, which is in a transition period. The challenges faced by female entrepreneurs in \\
Female, & the state of Kosovo, apart from economic factors, are also cultural factors. Given the role of small \\
$\begin{array}{l}\text { Transition, } \\
\text { Entrepreneurship, } \\
\text { Factors }\end{array}$ & businesses in the country's economic development, a number of these businesses are run by women, \\
& ventures also known as small businesses.
\end{tabular}

Through this research paper, we will try to highlight the main challenges of female entrepreneurs are facing in countries in transition, and especially in the state of Kosovo, where through the recommendations collected by this research paper, we believe that we will contribute to female entrepreneurs of this country.

\section{Introduction}

Worldwide, entrepreneurship is considered as an important segment of the country's economic development. One of the biggest advantages of entrepreneurship is the possibility of creating new jobs, which is particularly important for countries that are in the transition period, to help in strengthening the wellbeing of the citizens.

Female entrepreneurs come up with important concrete ideas that motivate economic growth, economic development and employment (Arbnore Abazi Salihaj, 2018).

Given that Kosovo is a country in transition, a country devastated by war, new ventures are much needed for this country. In addition to the economic development of the country, with the growth of women-led businesses, their empowerment is also important, especially in transition countries, which usually can be considered patriarchal societies like it's the case in Kosovo.
In addition, the impact of female entrepreneurs on competition, productivity and growth potentials of the country was not acknowledged and therefore women did not have sufficient support from society to achieve their entrepreneurial and managerial potential (Mirjana Radović-Markov, 2015)

There are two reasons why female entrepreneurs deserve academic research (Veland Ramadani, Shqipe Gërguri-Rashiti, Alain Fayolle, 2015):

$>$ Female entrepreneurs are known as an inexhaustible source of economic growth, considering the fact that they create jobs for themselves and for the society

$>$ Female entrepreneurship has traditionally been betrayed both by the society in general and by social sciences, given that fact that research, policies and programs have been "men streamed" 
The main reason for this research paper is that in our country, research in this field is scarce.

\section{Literature review}

A definition of female enterpreneurs can be as follows: "They are women who have certain financial capacities or who possess professional skills or who have also adept trainings in that particular field" (Hind Bouzekraoui, Driss Ferhane, 2017). Entrepreneurship is an idea or vision that a woman has to explore, which helps to create new jobs and economic empowerment of the country (Mohan Kumar, H.S. Chandrika Mohana, Vijaya Ca, Lokeshwari Na, 2013). Unfortunately, in the recent decades, research related to female entepreneurs has been scarce, especially in countries in transition period. Usually in countries in transtion only achievement of entrepreneurs are broght to the surface.

According to author Marjana (2015), today most of the knowledge about the activities of female entrepreneurs are from developed countries.

In the next five years, it is predicted that earnings to women of global size will have an increase from US $\$ 13$ trillion to US $\$ 18$ trillion. Forecasts give us a interesting figure, since according to them by 2028 women will control $75 \%$ of all expenditures in the world (Pula, 2016).

In a research conducted by author Sebiha in 2014, the number of female entrepreneurs are growing rapidly in the world. The factors that influence this growth of women in the global sectors are opportunities created by globalization, integrated markets and jobs, family support, large support from the government through various programs that started internationally and support by the government for female entrepreneurs, improving their standards, health as well as education (Sabiha Fazalbhoy, 2014)

Individually, women have made significant progress in the economy, but collectively their economic impact still remains moderate. Women own about 37 percent of firms globally; however, they hold high leadership positions in only about 18 percent of enterprises; and hold the position of Executive Directors in less than 5 percent of the world's largest enterprises (Riinvest, 2017).

According to a survey conducted in 2015 by the Global Enternprenreurship and Development Instute - GEDI, across 77 countries around the world, the top ten where women are doing enterprenual activities are the following: United States has a score of 82.9, continuing with Australia with a score of 74.8, United Kingdom 70.6, Denmark with 69.7, Netherlands 69.3, France 68.8, Iceland 68, Sweden with 66.7, Finland with 66.4 and Norway with a score of 66.3. (Siri Terjesen, Ainsley Lloyd, 2015).

Table 1. The top ten countries for female entrepreneurs

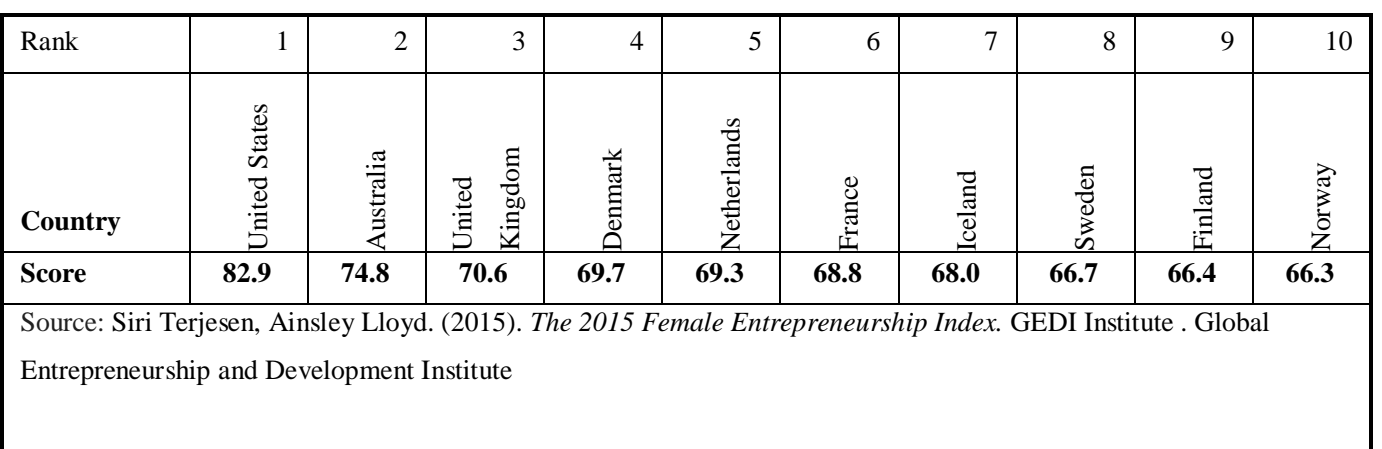

Women usually start their own businesses in the sectors, which are more attractive to them. The avarage age of women starting their businesses is from 25 to 34 years old in the least developed countries, while in developed countries women start their business from 25 to 44 years old (Merdža Handalić, 2009).

Cyprus as a small country, but with a lot of problems, $46 \%$ of female entrepreneurs are between 31 and 44 years old, where every second women has completed secondary school, while only $34 \%$ of them have completed their postgraduate studies. It is worth mentioing that their tendency is to continue their education.
$54 \%$ of young entrepreneurs have qualifications above the average level of education (Mateja Vadnjal, Jaka Vadnjal, 2015).

Female entrepreneurs have several advantages: opening up new firms, numerous innovations, opening up new jobs, and economic development of the country.

Figure 1. Linking entrepreneurship to economic growth 


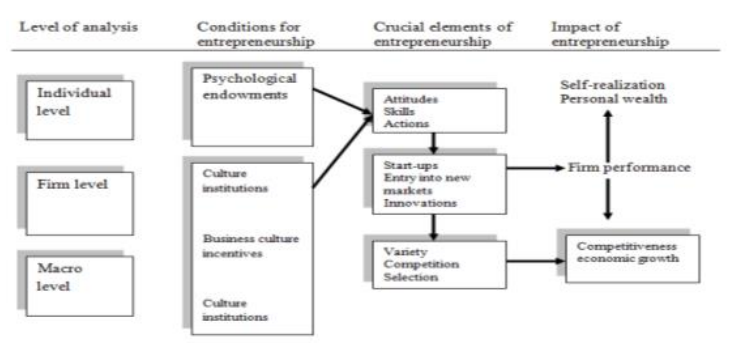

Source: Edona Haxhiu. (2015). The factors affecting success and performance of women entrepreneurs in Kosovo. Ljubljana, Slovenia: Master Thesis, University of Ljubljana, p.6

Fortunately, women nowadays are building programs to encourage women leaders in every institution. However, there is still room for improvement in this regard. The facts that need to be considered are as follows (Rrezarta Gashi, 2015):

$>$ Many companies want more diversity in decision making or a participatory female leadership style

$>$ Companies and the government have more interest in setting gender balance quotas

$>$ Women are "unused resources"

> The largest number of consumers are women, so they expect to deal with other women as well

According to the research conducted by Poonam Kain and Meenakshi Sharma in 2013, some of the most important factors affecting female entrepreneurs are said to be:

Figure 2: Most important factors affecting female entrepreneurs

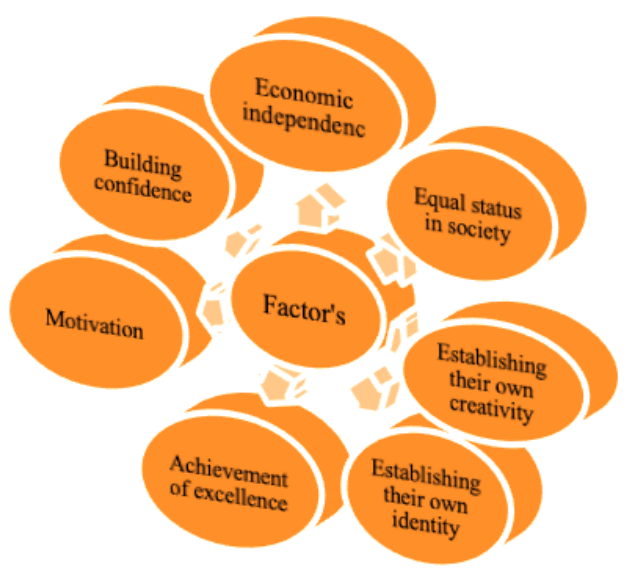

Source: Poonam Kain \& Meenakshi Sharma. (2013). Women Entrepreneurship Education Need for Today. Apeejay-Journal of Management Sciences and Technology (AJMST), 1 (1), 47
Unfortunately, female entrepreneurs face many challenges as opposed to male entrepreneurs. Women usually are faced with social prejudices, especially in those countries that are in the transition period (Arapi and others, 2017).

Some of the challenges faced by female entrepreneurs are: lack of capital, lack of professional staff, financial constraints due to large spending's, lack of vocational training (Siri Roland Xaviera, Syed Zamberi Ahmadb, Leilanie Mohd Nora, Mohar Yusofa, 2012).

Also, female entrepreneurs are often faced with a lack of capital, as it is well known that most of the household's capital are inherited by male, not female family members, this phenomenon is particularly largely present in countries in transition. In the absence of capital, it is likely that even startups fail, because they lack capital.

Another challenge for female entrepreneurs is the lack of adequate training to assist them in improving their managerial and technical skills, and to solve imminent production problems, thus improving productivity and increasing success (Fungai Ngoma Mauchi, Margaret Mutengezanwa, David Damiyano, 2014)

Another challenge specific to female entrepreneurs is also the socio-cultural ones, where it is known that in developing countries the prejudices for these women are common. Women are expected to play multiple roles, including family ones, which is a major obstacle to them (Bharthvajan R, 2014)

"The challenges in industry happen when entrepreneurs could not identify an appropriate industry and able to give profits. Challenges in this industry include problems in obtaining capital financing from the banks, do not understand the business methods in the industry that they involved, problems in creating an appropriate network, competition with other businesses and the problems in ensuring the products or services offered are appropriate with the needs of consumers, the ability of the entrepreneurs in putting their business as a catalyst for the state economy and be a prime initiator pooling of state resources. These challenges represent a heavy responsibility to be shouldered by female entrepreneurs" (Iklima Husna Abdul Rahim, Noor Fzlinda Fabeil, Toh Pei Sung, 2017).

There are many reasons for promoting entrepreneurial education, but three of them are the most important (Elona Garo, 2015)

$>$ Entrepreneurship is projected as the main force of the economy in the twenty-first century.

$>$ The need for an inter-functional integration of knowledge will be the future of business education.

$>$ There is a need for contemporary educators to understand not only their specialty but also the business system as a whole 


\section{Push and pull factors in entrepreneurs}

In literature we encounter two types of factors: push and pull. We can describe the pull factor or we can look at them as external stimulators, like the average industry expectations and its effects on expected profit, market opportunities in relation to those situations where goods, services, raw materials and ways of organization can be used and sold at a higher price compared to the price of their production, attracting people to become entrepreneurs (Mario Çurçija, 2015)

Whereas the push factors are, entrepreneurial motivational factors, which are not the same for all people, but are usually related to their surrounding environment and personal traits of the individuals (Francesco Quatraro, Marco Vivarelli, 2013)

The difference in the perception of general push and pull factors is that pull factors could account for average industry expectations and its effects on expected profit, market opportunities in relation to those where goods, services, raw materials and organizational ways can be used and sold at a price higher than the price of their production, attracting people to entrepreneurship, while push factors can be accounted for as incentive factors for entrepreneurship of an initiative arising from the need, not the opportunity displayed (Mario Çurçija, 2015).

According to the author Fauzia (2018), pull factors to female entrepreneurs can be considered the following: personal successes and achievements, economic independence, rejecting stereotypical feminine identities, using personal ideas, opening and developing family businesses, gaining a higher social status.

While push factors for female entrepreneurs can be considered: unemployment, lack of higher education, lack of skills, lack of work experience, and lack of institutional and family support (Fauzia Jabeen, 2018).

\section{Female entrepreneurs in Kosovo}

In recent years, Kosovo has made its efforts to promote the advancement of equality and in fighting the discrimination of women, especially the advancement of women in leadership positions, but still the country faces many challenges in exploiting the potential of women in the labor market.

The Kosovo Labor Force Survey in 2012 has released the following statistics that talk about the gender gap in employment (Nazmi Pllana, Business Support Center Kosovo, 2016):

$>$ Less than one in five $(17.8 \%)$ women of working age are active in the labor market, compared to more than half of men $(55.4 \%)$ of working age;
$>$ Among the labor force, unemployment is much higher among women compared to men $(40.0 \%$ and $28.1 \%$ respectively);

$>\quad$ The employment rate of women of working age is only $10.7 \%$ whereas it is $39.9 \%$ for men

In Kosovo $13 \%$ of businesses are owned by women, of which $95 \%$ are micro businesses with 1 to 10 employees. (Kosovo Democratic Institute, 2017). The number of women entrepreneurs in Kosovo is also among the lowest in the region, and women often face more hurdles than men while trying to establish a business (USAID, 2015).

Below are appeared the percentage of individual businesses during 2017 in Kosovo, both genders (MTI, ARBK, 2018).

Table 2: Percentage of Individual Business in Kosovo by gender, 2017

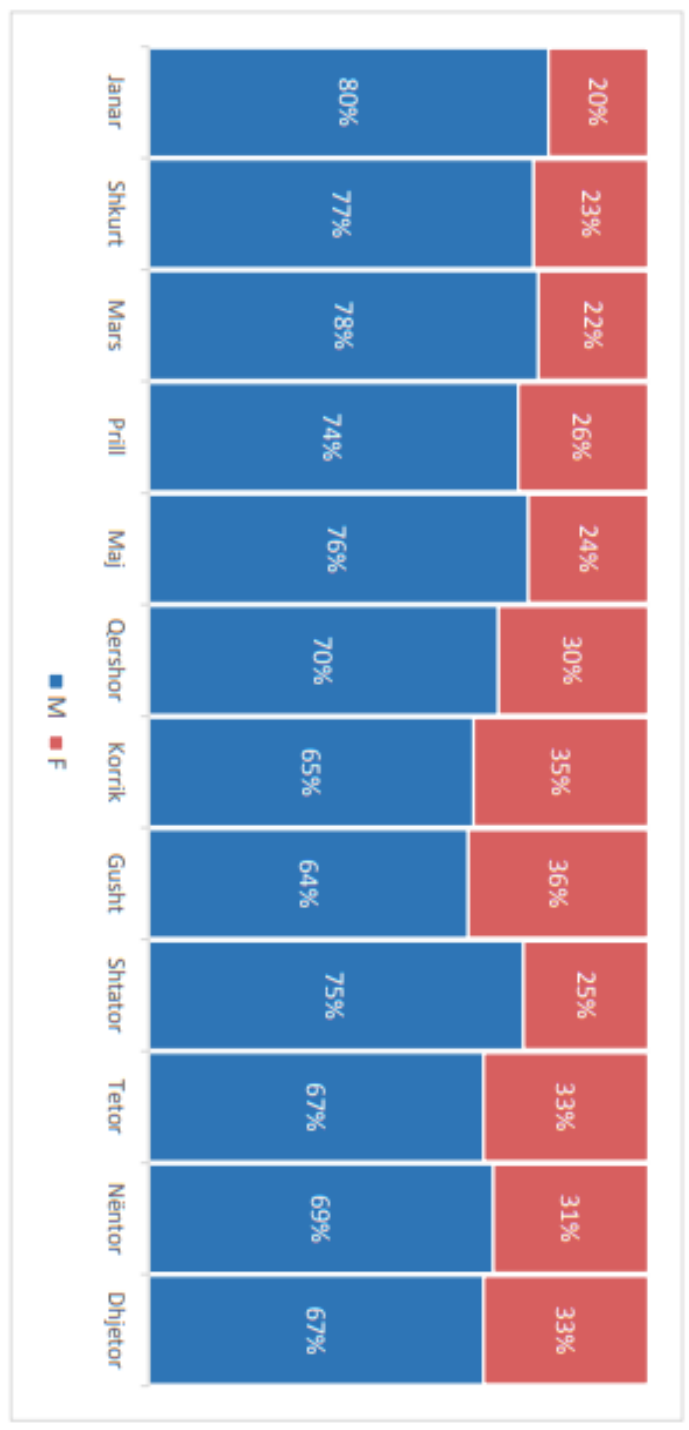

Source: MTI, ARBK. (2018). arbk.rks-gov.net 
Although in a very small number, recently in our country we have seen awareness that women, can be leadership of successful businesses. They face many problems, just like women in other countries, such as: lack of training, lack of initial capital, lack of professionalism in certain areas, etc.

The table below shows the percentage and number of new businesses owned by women and men (Frédéric Meunier, Yulia Krylova, Rita Ramalho, 2017)

Table 3. Economies with the most significant growth in the proportion of new female business owners

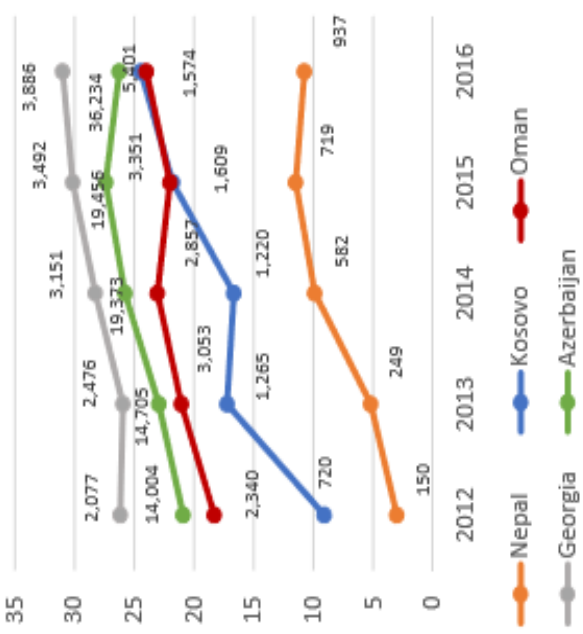

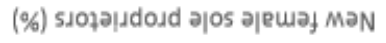

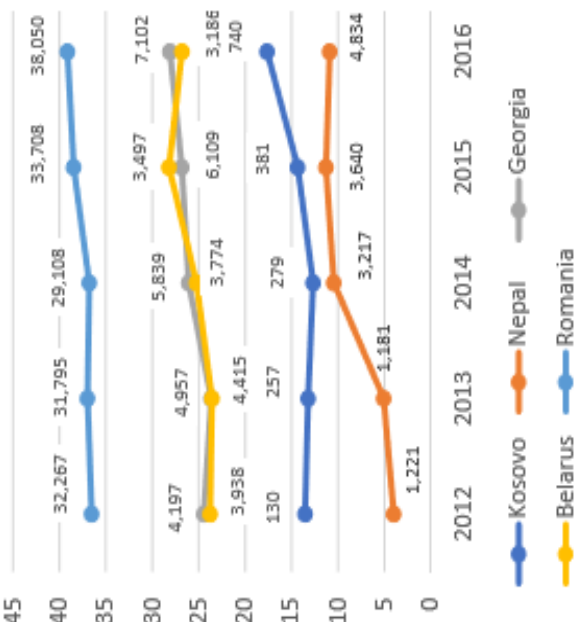

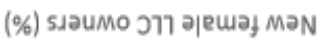

Source: Frédéric Meunier,Yulia Krylova, Rita Ramalho. (2017). Women's Entrepreneurship- How to Measure the Gap between New Female and Male Entrepreneurs? World Bank Group, p.10
Like in other developing countries, women in the state of Kosovo face lack of access to inheritance. Most women, especially those in rural areas, are not entitled to their inheritance, although by law, males and females have equal rights in inheritance (Assembly of Kosovo, 2004).

Kosovo as a transitional country has many projects, nongovernmental organizations that are in support of female entrepreneurs. According to a research conducted by Riinvest Institute related to female entrepreneurs in the state of Kosovo, it reveals that there are three high barriers: tax rates, small market, and administrative burden. Other barriers, which are specific to female entrepreneurs are, lack of time for specific training and family obligations, these two are ranked highest. In general, female, compared to male entrepreneurs, rank barriers with lower intensity (Riinvest, 2017).

\section{Research methodology}

The primary data of this research was gathered via a quantitative questionnaire composed of 19 questions. The questionnaire was previously used in a similar study, thus no piloting of the questionnaire to test its feasibility was applied (Arbnore Abazi Salihaj, 2018). Questionnaire contained single option questions, while some questions had more than one answer option.

Data was gathered during the period of January through February 2019. The questionnaire was distributed to 135 female entrepreneurs throughout the territory of Kosovo, where their selection was done using a snowball effect. Data processing and validation was done in excel, whereas, primary data will be presented through descriptive statistical analyzes.

Secondary data used are from similar research published in various scientific reports and publications were considered.

\section{Following are the research questions:}

$>\quad$ What are the main challenges influencing the success of female entrepreneurs in Kosovo?

$>$ Who are the biggest supporters of female entrepreneurs in Kosovo?

Following is the hypothesis of the research:

$>$ The clarity of thinking to be in depended, extension investment in training, and building an institutional and family support system are the challenges facing women entrepreneurs in Kosovo 


\section{Research analysis}

The opinion of 135 female entrepreneurs distributed in all major cities all over Kosovo, coming from different age groups with different educational background and field of operating businesses, mainly coming from small businesses was taken as a sample for the purpose of this research, that in order to ensure as much of a representative sample as possible considering the nature of the study but also taking into consideration the limited statistical data available in order to draw a statistically representative sample.

Table 4. Descriptive analyzes

\begin{tabular}{|l|r|r|}
\hline City & Frequency & Percentage \\
\hline Prishtina & 31 & $22.96 \%$ \\
\hline Peja & 14 & $10.37 \%$ \\
\hline Gjakova & 15 & $11.11 \%$ \\
\hline Prizren & 18 & $13.33 \%$ \\
\hline Ferizaj & 12 & $8.89 \%$ \\
\hline Lipjan & 4 & $2.96 \%$ \\
\hline Skenderaj & 6 & $5.93 \%$ \\
\hline Suharek & 11 & $8.15 \%$ \\
\hline Gjilan & 7 & $5.19 \%$ \\
\hline Vushtri & 9 & $6.67 \%$ \\
\hline Mitrovice & $\mathbf{1 3 5}$ & $\mathbf{1 0 0 . 0 0 \%}$ \\
\hline Total & & \\
\hline
\end{tabular}

On this table appeared cities in which the questionnaires have been distributed. In total are 11 cities in total, a total of 135 respondents.

Table 5. Age of respondents

\begin{tabular}{|c|c|c|}
\hline Age of respondents & Answers & Percentage \\
\hline $20-30$ age & 15 & $11 \%$ \\
\hline $31-40$ age & 42 & $31 \%$ \\
\hline $41-50$ age & 47 & $35 \%$ \\
\hline $51-60$ age & 31 & $23 \%$ \\
\hline & 135 & $100 \%$ \\
\hline
\end{tabular}

In Table 5, appeared the respondents' age, which appeared that the largest percentage is made up of women aged 41-50 years with $47 \%$, while their lowest percentage consists of women aged 20-30 years with $11 \%$.
Table 6. Status of respondent

\begin{tabular}{|l|r|r|}
\hline $\begin{array}{l}\text { Status } \\
\text { respondent }\end{array}$ & Answers & Percentage \\
\hline Not married & 32 & $24 \%$ \\
\hline Married & 82 & $61 \%$ \\
\hline Divorced & 21 & $16 \%$ \\
\hline & 135 & $100 \%$ \\
\hline
\end{tabular}

Table 7. Education of respondent

\begin{tabular}{|l|r|r|}
\hline $\begin{array}{l}\text { Education of } \\
\text { respondent }\end{array}$ & \multicolumn{1}{c|}{ Answers } & Percentage \\
\hline Secondary school & 23 & $17 \%$ \\
\hline Bachelor & 65 & $48 \%$ \\
\hline Master degree & 45 & $33 \%$ \\
\hline $\mathrm{PhD}$ & 2 & $1 \%$ \\
\hline & 135 & $100 \%$ \\
\hline
\end{tabular}

In Table 6, the status of respondents is appeared, with 32 of them not married, 82 of them are married, and 21 of them are divorced. Based on the table 7, it is seen that 65 out of 135 respondents are more bachelor studies, followed by master studies with 45 , while only 2 of them have $\mathrm{PhD}$.

Table 8. Are they equally supported by society and the family as women entrepreneurs just like men?

\begin{tabular}{|l|l|l|}
\hline $\begin{array}{l}\text { Are they equally supported } \\
\text { by society and the family as } \\
\text { women entrepreneurs just } \\
\text { like men? }\end{array}$ & Answers & Percentage \\
\hline Yes & 42 & $31 \%$ \\
\hline No & 93 & $69 \%$ \\
\hline & 135 & $100 \%$ \\
\hline
\end{tabular}

In the question "Are they equally supported by society and the family as women entrepreneurs just like men", which is shows above, 93 of them have responded NO, while only 42 have responded with YES.

Table 9. How satisfied is the institutional support for women entrepreneurs?

\begin{tabular}{|l|l|l|}
\hline $\begin{array}{l}\text { How satisfied is the institutional } \\
\text { support for women } \\
\text { entrepreneurs? }\end{array}$ & Answers & Percentage \\
\hline Not at all satisfied & 45 & $33 \%$ \\
\hline
\end{tabular}




\begin{tabular}{|l|l|l|} 
Satisfied & 69 & $51 \%$ \\
\hline Very satisfied & 21 & $16 \%$ \\
\hline & 135 & $84 \%$ \\
\hline
\end{tabular}

On the question "How satisfied is the institutional support for women entrepreneurs", the responses that are presented in table no.9, 45of them have responded are not satisfy, 69 of them are satisfied and 21 of them have responded that are very satisfying.

Table 10. Women in Kosovo are

\begin{tabular}{|l|r|}
\hline Women in Kosovo are: & Answers \\
\hline Discriminated & 52 \\
\hline Not discriminated & 32 \\
\hline $\begin{array}{l}\text { There is no gender equality } \\
\text { between women and men }\end{array}$ & 60 \\
\hline $\begin{array}{l}\text { There is gender equality } \\
\text { between women and men }\end{array}$ & 55 \\
\hline Need support & 135 \\
\hline Have support by family & 75 \\
\hline Are biased & 63 \\
\hline Are not biased & 52 \\
\hline
\end{tabular}

Results in table 10 are: Since this question had more than one answer, the results are as follows: 52 responses are that women are discriminated, 32 responses are that they are not discriminated, 60 say that there is no gender equality between men and heavy, 55 say there is equality between men and women, 75 of them say they are supported by the tire family, 63 responses are that they are biased, 52 of them are that they are not biased, all have the answer that women entrepreneurs need support, whether family or institutional.

Table 11. Are you a participant of any organization or forum of women entrepreneurs in Kosovo

\begin{tabular}{|l|r|r|}
\hline $\begin{array}{l}\text { Are you a participant of } \\
\text { any organization or forum } \\
\text { of women entrepreneurs } \\
\text { in Kosovo? }\end{array}$ & Answers & Percentage \\
\hline Yes & 95 & $70 \%$ \\
\hline No & 40 & $30 \%$ \\
\hline & 135 & $100 \%$ \\
\hline
\end{tabular}

When asked "Are you a participant of any organization or forum of women entrepreneurs in Kosovo", 40 of them have the responses that they are not participating in any women's entrepreneurship organization, while 95 of them have a positive response.
Table 12. Do you know about any local or world-wide organization that provides help to women entrepreneurs?

\begin{tabular}{|c|c|c|}
\hline $\begin{array}{l}\text { Do you know about any } \\
\text { local or world-wide } \\
\text { organization that provides } \\
\text { help to women } \\
\text { entrepreneurs? }\end{array}$ & Answers & Percentage \\
\hline Yes & 121 & $90 \%$ \\
\hline \multirow[t]{2}{*}{ No } & 14 & $10 \%$ \\
\hline & 135 & $100 \%$ \\
\hline
\end{tabular}

Answer of question "Do you know about any local or world-wide organization that provides help to women entrepreneurs", 121 of them responded YES, while only 14 responded NO.

Table 13. Have you been a beneficiary of any donation to women entrepreneurs

\begin{tabular}{|l|r|r|}
\hline $\begin{array}{l}\text { Have you been a } \\
\text { beneficiary of any } \\
\text { donation to women } \\
\text { entrepreneurs? }\end{array}$ & Answers & Percentage \\
\hline Yes & 96 & $71 \%$ \\
\hline No & 39 & $29 \%$ \\
\hline & 135 & $100 \%$ \\
\hline
\end{tabular}

Answer of question "Have you been a beneficiary of any donation to women entrepreneurs "96 out of 135 respondents have responded that received donations, while only 35 of them did not benefit from donations.

Table 14. How many workers do you have

\begin{tabular}{|l|r|r|}
\hline $\begin{array}{l}\text { How many workers do } \\
\text { you have? }\end{array}$ & Answers & Percentage \\
\hline 1-5 workers & 34 & $25 \%$ \\
\hline 6-15 workers & 67 & $50 \%$ \\
\hline $16-30$ workers & 22 & $16 \%$ \\
\hline 30 and over & 12 & $9 \%$ \\
\hline & 135 & $100 \%$ \\
\hline
\end{tabular}

34 of the interviewers had a small business from 1 to 5 employees, 67 of them 6-15 employees, 22 of them had 16-30 employees, while 12 of them had more than 30 employees in their business.

Table 15. Your business has this sector

\begin{tabular}{|l|r|r|}
\hline $\begin{array}{l}\text { Your business has this } \\
\text { sector: }\end{array}$ & Answers & Percentage \\
\hline Productivity & 60 & $44 \%$ \\
\hline Medical services & 4 & $3 \%$ \\
\hline
\end{tabular}




\begin{tabular}{|l|r|r|} 
Aesthetic services & 42 & $31 \%$ \\
\hline Real estate & 7 & $5 \%$ \\
\hline Agriculture & 16 & $12 \%$ \\
\hline Finances & 6 & $4 \%$ \\
\hline & 135 & $100 \%$ \\
\hline
\end{tabular}

Fortunately, most of the answers to the question presented in table no 15 are with production, 60 or $44 \%$ of them, followed by 42 of them with aesthetic services, 16 with agriculture, of them with real estate, 6 with finance and at all end with medical services, only 4 of them.

Table 16. Are you ignored by men who operate in the same business field as you are?

\begin{tabular}{|c|c|c|}
\hline $\begin{array}{l}\text { Are you ignored } \\
\text { by men who } \\
\text { operate in the } \\
\text { same business } \\
\text { field as you are? }\end{array}$ & Answers & Percentage \\
\hline Yes & 87 & $64 \%$ \\
\hline \multirow[t]{2}{*}{ No } & 48 & $36 \%$ \\
\hline & 135 & $100 \%$ \\
\hline
\end{tabular}

On the question "Are you ignored by men who work in the same business field as you are", 87 out of 135 respondents responded YES, while 48 of them have responded NO.

Table 17. Are there any thoughts on women that they are a major factor for economic growth

\begin{tabular}{|l|r|r|}
\hline $\begin{array}{l}\text { Are there any thoughts on } \\
\text { women that they are a major } \\
\text { factor for economic growth? }\end{array}$ & Answer & Percentag \\
\hline There is no progress & 35 & $26 \%$ \\
\hline There is little progress & 43 & $32 \%$ \\
\hline There is enough progress & 57 & $42 \%$ \\
\hline & 135 & $100 \%$ \\
\hline
\end{tabular}

Fortunately, 57 of the respondents think that women have enough progress in the country's economic growth, while 43 of them think they have little progress, while 35 believe that there is no progress in this regard.

Table 18. What are the challenges for women entrepreneurs

\begin{tabular}{|l|r|}
\hline $\begin{array}{l}\text { What are the challenges for } \\
\text { women entrepreneurs? }\end{array}$ & Answers \\
\hline Lack of initial capital & 58 \\
\hline Lack of training & 100 \\
\hline Lack of institutional support & 115 \\
\hline
\end{tabular}

High interest rates 135

Bases in table no 18 appear that all women entrepreneurs face high credit interest rates, continuing with insufficient institutional support, lack of initial capital, as well as lack of training.

Table 19. Have you taken credit for opening a business

\begin{tabular}{|l|r|r|}
\hline $\begin{array}{l}\text { Have you taken credit } \\
\text { for opening a business? }\end{array}$ & Answers & Percentage \\
\hline Lack of initial capital & 120 & $89 \%$ \\
\hline Lack of training & 15 & $11 \%$ \\
\hline & 135 & $100 \%$ \\
\hline
\end{tabular}

Unfortunately, about 120 or $89 \%$ of female entrepreneurs interviewed have received credits from the bank for opening their business, while only 15 or $11 \%$ of them have not received credits.

\subsection{Hypothesis authentication}

The hypothesis of submitted in this research is based in the descriptive analysis. Hypothesis "The clarity of thinking to be in depended, extension investment in training, and building an institutional and family support system are the challenges facing women entrepreneurs in Kosovo" we can say it has been verified, since 100 respondents from 135 involved in this research have said that they lack training in the operating market, 115 responses are lacking in institutional support, 75 or $56 \%$ responded that they have lack of family support. Women, as opposed to men, are also ignored in the same field of business. All women who were part of this research said they needed to support them. Thus, the biggest challenges faced by women entrepreneurs in Kosovo are: lack of training, lack of institutional and family support, women are also prejudiced and discriminated.

\section{Discussions and recommendations}

During the research we have noticed that women face many challenges. Many are discriminated against, and/or are faced with prejudice. Another challenge, which unfortunately a big challenge for female entrepreneurs, is the lack of institutional support. In every country of the world, institutions play an important role in any development. However, given that Kosovo is a country in transition, lack of institutional support is being noticed in every aspect. Also high credit interest rates are another challenge for women entrepreneurs, as currently Kosovo evidently has the highest interest rates in the region.

Nevertheless, the interest of women to engage the business activities in Kosovo is very high. By offering them more training and support, they would be even more motivated and we would have a higher percentage of female involvement in the business 
sector. At the same time, female entrepreneurs also have a positive impact on the economic development of the country, as it is known that the economies of the countries are influenced by small and medium-sized businesses, and entrepreneurs are mainly small businesses, that usually within a short period of time many of them grow into middle-sized businesses.

Based on the results of the research done, female entrepreneurs are usually managing small businesses, with a small number of employees.

According to our sample 60 of them claim that there is no gender equality between men and women.

The recommendations given for this research are as follows:

- Family support of female entrepreneurs should continuously grow

- Institutional support should grow like in developed countries. Separate budget should be dedicated to the support of female entrepreneurs

- $\quad$ Banking institutions should offer lower interest rates for female entrepreneurs with a longer period of time of return.

- Provide opportunities for various trainings locally and abroad, as it is known that trainings plays a major role in developing of managerial skills,

- There should be more non-governmental organizations that are specifically involved with female entrepreneurs and lobby for their support

- Non-governmental organizations have cooperation with international nongovernmental organizations in order to exchange their experiences.

\section{References}

1. Merdža Handalić. (2009). The Position of Female Entrepreneurs in the European Union and Transition Countries. Journal of woman's entrepreneurship and education, 1 (2), 17.

2. Arbnore Abazi Salihaj. (2018). Impact of cultural factor on women entrepreneurs in economy: Kosovo case

3. . Master Thesis, Prishtine.

4. Bharthvajan R. (2014). Women Entrepreneurs \& Problems Of Women Entrepreneurs. International Journal of Innovative Research in Science, Engineering and Technology, 3 (9), 16109.

5. Edona Haxhiu. (2015). The factors affecting success and performance of women entrepreneurs in Kosovo. Ljubljana, Slovenia: University of Ljubljana.
6. Elona Garo. (2015). The determining factors of the entrepreneurial will of the Albanian youth

7. . Tirane: University of Tirana.

8. Fauzia Jabeen. (2018, 2). www.researchgate.net. Retrieved 25, 2019, from https://www.researchgate.net/publication/323345816_Pu sh_and_Pull_Model_of_Women_Entrepreneurship_Empi rical_Evidence_from_the_UAE

9. Fellanze Pula. (2016). Business oriented by women-case study; Kosovo European University of Tirana, Phd Thesis, Tirane.

10. Francesco Quatraro, Marco Vivarelli. (2013). Entrepreneurship in a developing country context. Torino, Italy: Department of Economics and Statistics "COGNETTI DE MARTIIS".

11. Frédéric Meunier,Yulia Krylova, Rita Ramalho. (2017). Women's Entrepreneurship- How to Measure the Gap between New Female and Male Entrepreneurs? World Bank Group.

12. Fungai Ngoma Mauchi, Margaret Mutengezanwa, David Damiyano . (2014). Challenges faced by women entrepreneurs: A case study of Mashonaland Central Province . International Journal of Development and Sustainability , 3 (3), 471.

13. Hind Bouzekraoui, Driss Ferhane. (2017). An Exploratory Study of Women's Entrepreneurship in Morocco. IBIMA Publishing: Journal of Entrepreneurship: Research \& Practice, 2017, 2.

14. Iklima Husna Abdul Rahim, Noor Fzlinda Fabeil, Toh Pei Sung. (2017). Motivator and challenges of women entrepreneurs. Journal of Global Business and Social Entrepreneurship (GBSE), 1 (3), 115.

15. KDI . (2017). Supporting Women with Business VitalityThe Only Solution. Kosovo Democratic Institute.

16. Parliament of Kosovo. (2004). Retrieved 2 15, 2019, from http://assemblykosova.org/common/docs/ligjet/2004_26_al.pdf

17. Mario Çurçija. $(2015,11)$. researchgate.net. Retrieved 1 20, 2019, from https://www.researchgate.net/publication/325625903_ Entrepreneurship promoters in academic literature.

18. Mateja Vadnjal, Jaka Vadnjal. (2015). Female Entrepreneurs' Start-Ups: Emotional Versus Traditional Support. In S. G.-R. Veland Ramadani, Female Entrepreneurship in Transition Economies:Trends and Challenges (p. 46). Palgrave Macmillan.

19. Mirjana Radović-Markov. (2015). Female Entrepreneurship in Transition Economies: An Overview. In S. G.-R. Veland Ramadani, Female Entrepreneurship in Transition Economies (p. 9). Palgrave Macmillan. 
20. Mohan Kumar, H.S. Chandrika Mohana, Vijaya Ca, Lokeshwari Na. (2013). The Role of Women Entrepreneurship in Modern World. International Journal of Current Engineering and Technology (Special Issue 1), 102.

21. MTI, ARBK. (2018, 9). arbk.rks-gov.net. Retrieved 2 19, 2019, from https://arbk.rksgov.net/desk/inc/media/89559804-7DF3-46C4-A3A7DF4A1DB15ED4.pdf

22. Nazmi Pllana, Kosovo Center for Business Support. (2016). Strategy for women entrepreneurs in the municipality of Kamenica for the period 2017-2022. Prishtine.

23. Poonam Kain, Meenakshi Sharma. (2013). Women Entrepreneurship Education Need for Today. ApeejayJournal of Management Sciences and Technology (AJMST), 1 (1), 47.

24. Riinvest. (2017). Women's Entrepreneurship - Analysis of Business Doing Business in Kosovo. Prishtine.

25. Rrezarta Gashi. (2015). Strategic Management Role on Contemporary Emerging Market - The Female Economy . Mediterranean Journal of Social Sciences , 6 (3), 158.

26. Sabiha Fazalbhoy. (2014). Women Entrepreneurship as the Way. Annual Research Journal of Symbiosis Centre for Management Studies, Pune, 2 (1), 122.

27. Siri Roland Xaviera, Syed Zamberi Ahmadb, Leilanie Mohd Nora, Mohar Yusofa. (2012). Retrieved 12 12, 2018, from elsevier.com: https://www.sciencedirect.com/science/article/pii/S22125 $\underline{67112003474}$

28. Arapi, D., Vardari, L., \& Gashi, R. (2018). A A Women in The Labour Market and Decision Making in Kosovo. PRIZREN SOCIAL SCIENCE JOURNAL, 1(1), 15-29.

Retrieved from http://prizrenjournal.com/index.php/PSSJ/article/vie $\underline{w} / 6$

29. Siri Terjesen, Ainsley Lloyd. (2015). The 2015 Female Entrepreneurship Index. GEDI Institute . Global Entrepreneurship and Development Institute.

30. USAID. (2015, 11). Retrieved 1 15, 2019, from usaid.gov: https://www.usaid.gov/sites/default/files/success/files/Gr at $\%$ C3\% AB\%20po\%20P\%C3\%ABrparojn\%C3\% AB\%2 0n\%C3\%AB\%20Sektorin\%20Afarist\%20t\%C3\%AB\%2 0Kosov\%C3\%ABs.pdf

31. Veland Ramadani, Shqipe Gërguri-Rashiti, Alain Fayolle. (2015). Female Entrepreneurship in Transition Economies. Palgrave Macmillan. 